\section{References}

Fry, J. (1968). Schweizerische medizinische Wochenschrift, 98, 1210

Lawrie, D. M., et al. (1967). Lancet, 2, 109.
Lown, B., Fakhro, A. M., Hood, W. B., jun., and Thorn, W. (1967). fournal of the American Medical Association, 199, 188.
. Nichols, J. B. (1968). Practitioner, 200, 700.

Norris, R. M., Brandt, P. W. T., and Lee, A. J. (1969). Lancet, 1, 278.
Pentecost, B. L., and Mayne, N. M. C. (1968). British Medical Fournal, 1,830 .

Sleet, R. A. (1968). British Medical fournal, 4, 675.

Thomas, M., Jewitt, D. E., and Shillingford, J. P. (1968). British Medical Fournal, 1, 787

World Health Organization (1959). Technical Report Series, No. 168

Wright, H. J. (1964). Unpublished data.

\title{
Resistance of the Breast-fed Infant to Gastroenteritis
}

\author{
CATHERINE L. BULLEN, A. T. WILLIS
}

British Medical fournal, 1971, 3, 338-343

\section{Summary}

From in-vitro studies of breast and cow's milk preparations, and of the faeces from breast-fed and bottle-fed infants, a number of factors seemed likely to influence the production and maintenance of a lactobacillary flora and low pH in the faeces of newborn infants. These were mainly attributable to the nature of the feed. It is suggested that responsible factors in breast milk include its high lactose, low protein, low phosphate content, together with its poor buffering capacity. Importance is also attached to the fact that breast milk seems to provide a fluid feed of small bulk and low residue, and that its use is unlikely to include periods of starvation. Cow's milk, on the other hand, which has a low lactose, high protein, high phosphate content, and a high buffering capacity, is a relatively bulky, high-residue feed. Feeding regimens which employ it are likely to include periods of starvation.

\section{Introduction}

It has been recognized for many years that breast-fed babies are relatively resistant to gastroenteritis (Alexander, 1948; Ross and Dawes, 1954; Hinton and MacGregor, 1958). The continuing incidence of enteropathogenic Escherichia coli infections in young infants, together with the decline in popularity of breast-feeding, led us to a study of this problem. Breast-fed infants differ from bottle-fed infants in two outstanding ways-(1) the microbiological and physicochemical properties of the faeces, and (2) the composition of the feed. Because it seems likely that the first is partly dependent on the second we have carried out some in-vitro studies in an effort to explore this relationship.

The present communication summarizes the findings of this study.

\section{Methods and Results}

\section{INFANT FAECES}

Initial experiments were performed to confirm earlier observations concerning the nature of the bacterial flora and the $\mathrm{pH}$ values of faeces from totally breast-fed and artificially-fed

\footnotetext{
Public Health Laboratory, Luton and Dunstable Hospital, Luton, Beds

CATHERINE L. BULLEN, M.R.C.v.s., Senior Scientist

A. T. WILLIS, M.D., M.R.C.PATH., Director
}

newborn infants. The bottle-fed infants received a variety of commercial dried cow's milk preparations. Ten breast-fed and 21 bottle-fed babies were included in the survey; 9 of these were home deliveries ( 4 breast-fed and 5 bottle-fed infants) and 22 were hospital confinements ( 6 breast-fed and 16 bottle-fed infants). Whenever possible faecal specimens including meconium were collected from birth for the first 28 days of life. In the case of home confinements the first faecal specimen examined was commonly collected towards the end of the first week, whereas in hospital-delivered babies the last specimen was commonly collected on the third or fourth day.

\section{BACTERIAL COUNTS}

Bacterial counts performed by the method of Miles et al. (1938) on faecal specimens commonly showed a relative and absolute numerical preponderance of anaerobic lactobacilli in specimens from breast-fed infants; the highest viable counts of lactobacilli were of the order of $10^{10}$ organisms/g of faeces, in contrast to $E$. coli/coliform counts, which never reached $10^{10}$ organisms $/ g$. Similar counts performed on the faeces of bottle-fed infants showed a reversed situation in which lactobacillus counts did not exceed $10^{8}$ organisms $/ g$, whereas $E$. coli/coliform counts were commonly in excess of $10^{10}$ organisms/g (Figs. 1-3). In the course of these investigations it was noted that the faeces from breast-fed infants never yielded organisms other than anaerobic lactobacilli, bacilli of the $E$. coli/coliform complex, and strains of anaerobic streptococci. Faeces from bottle-fed babies, on the other hand, commonly contained clostridia (notably $\mathrm{Cl}$. welchii and $\mathrm{Cl}$. tertium), Bacteroides and Proteus species, and Pseudomonas aeruginosa.

\section{WATER CONTENT AND PH VALUES}

The water content of faeces from breast-fed infants was always greater than that from bottle-fed babies; average values were $87 \%$ and $74 \%$ respectively (Table I). The pH values of the meconium from all 31 infants fell within the range 5.8-6.5. For the 10 breast-fed infants faecal $\mathrm{pH}$ values fell steadily during the first seven days to a mean value of $5 \cdot 1$. For bottle-fed infants, on the other hand, the mean values rose to $\mathrm{pH} 6.5$ (Fig. 4).

\section{REDUCING AND FERMENTABLE SUBSTANCES}

Reducing substances were detected by Benedict's method in the faeces of breast-fed but not of bottle-fed infants. Fermentation tests with $E$. coli and performed on sterilized emulsions of faeces in sugar-free media failed to show the presence of any fermentable substance in samples from bottle-fed infants. 


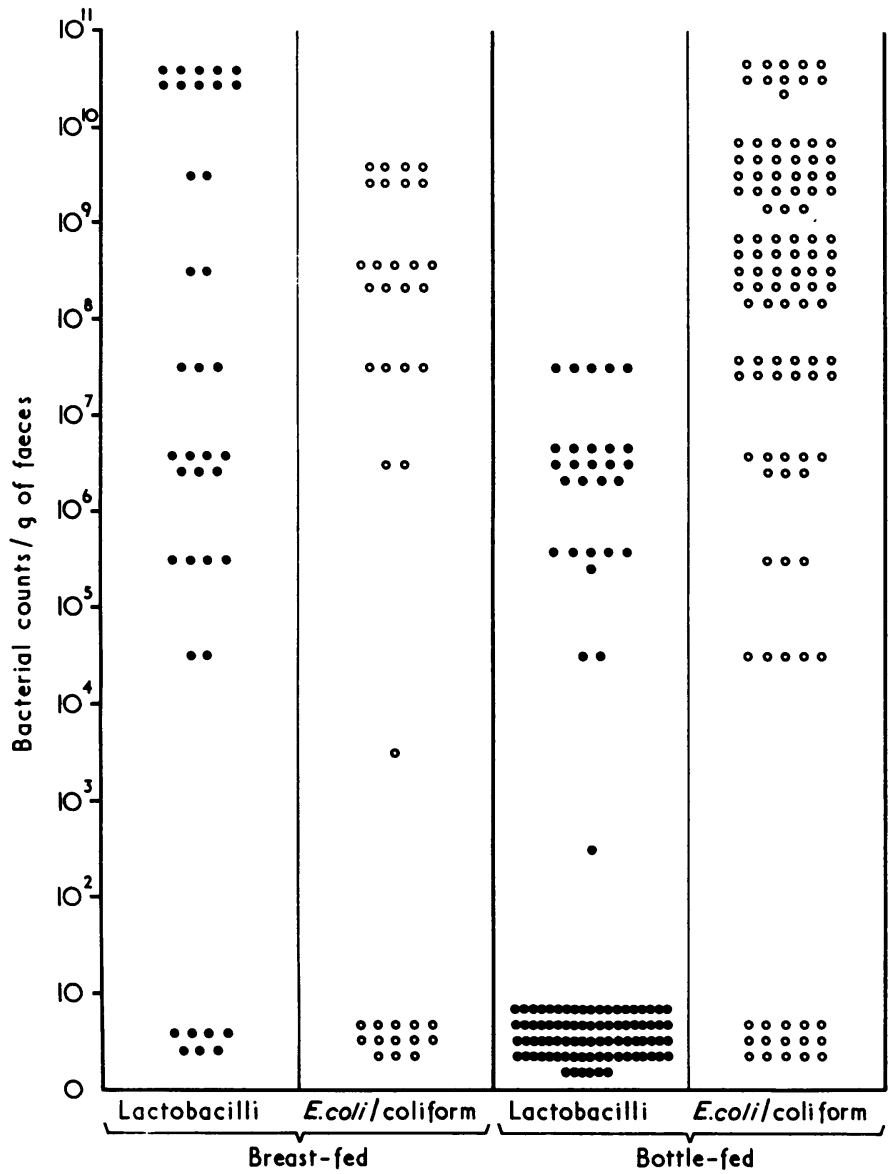

FIG. 1-Counts of lactobacilli ( $O$ ) and $E$. coli/coliform organisms (O) per gramme of faeces from breast-fed and bottle-fed infants. Each plot represents one sample. (Left: 37 samples from breast-fed infants. Right: 110 samples from bottle-fed infants.)

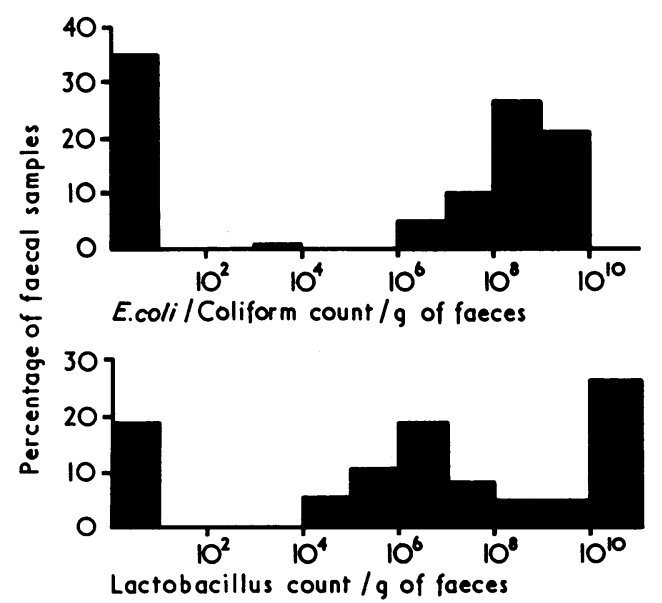

FIG. 2-E. coli/coliform counts (above) and lactobacillus counts (below) of faeces from breast-fed infants distributed as a percentage of 37 samples.

Cultures prepared from the faeces of breast-fed infants showed substantial fermentation. No quantitative estimations were performed.
TABLE I-Water Content of Faeces from Breast-fed and Bottle-fed Infants

\begin{tabular}{|c|c|c|c|c|c|c|c|c|}
\hline & \multirow{2}{*}{\multicolumn{6}{|c|}{ No. of Sample }} & \multicolumn{2}{|c|}{ Water Content ( $\mathrm{g} \%$ ) of Faeces from } \\
\hline & & & & & & & Breast-fed Infants & $\begin{array}{c}\text { Bottle-fed Infants } \\
92\end{array}$ \\
\hline $\begin{array}{l}1 \\
2 \\
3 \\
4 \\
5 \\
6 \\
7 \\
8 \\
9 \\
10 \\
11 \\
12 \\
13 \\
14 \\
15 \\
16 \\
17 \\
18 \\
19 \\
20 \\
21 \\
22 \\
23 \\
24 \\
25 \\
26 \\
27 \\
28 \\
29 \\
30 \\
31 \\
\end{array}$ & $\begin{array}{l}. \\
\because \\
\because \\
\because \\
\because \\
\because \\
\because \\
\because \\
\because \\
\because \\
\because \\
\because \\
\because \\
\because \\
\because \\
\because \\
\because \\
\because \\
\because \\
\because \\
\end{array}$ & $\begin{array}{l}. \\
\because \\
\because \\
\because \\
\because \\
\because \\
\because \\
\because \\
\because \\
\because \\
\because \\
\because \\
\because \\
\because \\
\because \\
\because \\
\because \\
\because \\
\therefore \\
\end{array}$ & $\begin{array}{l}\because \\
\because \\
\because \\
\because \\
\because \\
\because \\
\because \\
\because \\
\because \\
\because \\
\because \\
\because \\
\because \\
\because \\
\because \\
\end{array}$ & $\begin{array}{l}\because \\
\because \\
\because \\
\because \\
\because \\
\because \\
\because \\
\because \\
\because \\
\because \\
\because \\
\because \\
\because \\
\because \\
\because \\
\because \\
\because \\
\because \\
\end{array}$ & $\begin{array}{l}\because \\
\because \\
\because \\
\because \\
\because \\
\because \\
\because \\
\because \\
\because \\
\because \\
\because \\
\because \\
\because \\
\because \\
\because \\
\because \\
\because \\
\because \\
\because \\
\because \\
\end{array}$ & 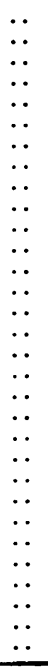 & $\begin{array}{l}99 \\
99 \\
99 \\
99 \\
92 \\
90 \\
89 \\
86 \\
85 \\
85 \\
84 \\
84 \\
84 \\
84 \\
83 \\
82 \\
82 \\
80 \\
80 \\
76 \\
= \\
= \\
= \\
= \\
= \\
=\end{array}$ & $\begin{aligned} 92 \\
92 \\
88 \\
86 \\
86 \\
80 \\
80 \\
80 \\
80 \\
80 \\
79 \\
79 \\
78 \\
78 \\
77 \\
77 \\
76 \\
75 \\
75 \\
75 \\
75 \\
74 \\
74 \\
73 \\
72 \\
71 \\
64 \\
59 \\
52 \\
39 \\
38 \\
\end{aligned}$ \\
\hline \multicolumn{2}{|c|}{ Mean } & . & . & $\cdots$ & . & .. & 87 & 74 \\
\hline
\end{tabular}

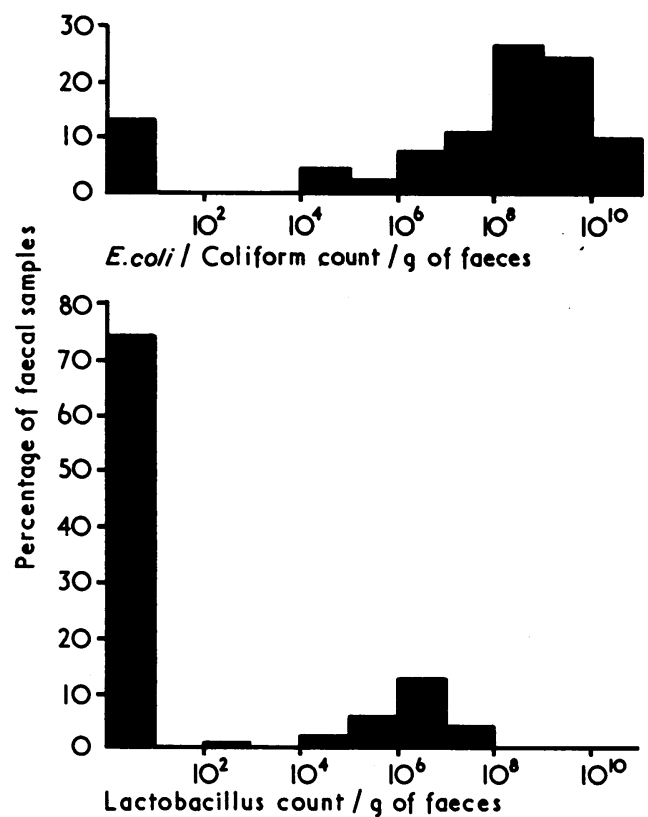

FIG. 3-E. coli/coliform counts (above) and lactobacillus counts (below) of faeces from bottle-fed infants distributed as a percentage of 110 samples.

\section{BUFFERING CAPACITY}

The buffering capacities of faecal emulsions in saline were determined for the two groups of infants by titration with $\mathrm{N} / 10$ lactic acid. The volume of acid required to reduce the $\mathrm{pH}$ of the faeces from 6.5 to 4.5 was two or three times greater for that from bottle-fed than that from breast-fed infants (Table II).

\section{PROTEIN CONTENT}

Samples of cow's milk, breast milk, and faeces from both breast-fed and bottle-fed infants were digested with trypsin and the supernatants were examined for their amino-acid 
patterns by thin-layer chromatography. The amino-acid patterns of cow's milk and of faeces from bottle-fed infants were similar but differed from the patterns of breast milk and of faeces from breast-fed infants. The amino-acid patterns of breast milk and of faeces from breast-fed infants were generally similar but differed in that there were fewer aminoacids present in the faecal material. These preliminary observations suggest that protein is less completely digested by bottle-fed than breast-fed infants.

TABLE II-Buffering Capacity of Faecal Specimens from Breast-fed and Bottlefed Infants

\begin{tabular}{|c|c|c|c|c|c|c|c|}
\hline \multirow{2}{*}{\multicolumn{2}{|c|}{$\begin{array}{c}\text { Sample } \\
\text { No. }\end{array}$}} & \multicolumn{3}{|c|}{ Breast-fed Infants } & \multicolumn{3}{|c|}{ Bottle-fed Infants } \\
\hline & & $\begin{array}{c}\text { Starting } \\
\text { pH }\end{array}$ & $\underset{\mathrm{pH}}{\text { Final }}$ & $\begin{array}{c}\text { Vol. of } \\
\text { N/10 } \\
\text { Lactic Acid } \\
\text { (ml) }\end{array}$ & $\begin{array}{c}\text { Starting } \\
\text { pH }\end{array}$ & $\underset{\mathrm{pH}}{\text { Final }}$ & $\begin{array}{c}\text { Vol. of } \\
\text { N/10 } \\
\text { Lactic Acid } \\
\text { (ml) }\end{array}$ \\
\hline $\begin{array}{r}1 \\
2 \\
3 \\
4 \\
5 \\
6 \\
7 \\
8 \\
9 \\
10\end{array}$ & $\begin{array}{l}\ldots \\
\cdots \\
\cdots \\
\cdots \\
\because \\
\cdots \\
\therefore\end{array}$ & $\begin{array}{l}4 \cdot 75 \\
4 \cdot 8 \\
5 \cdot 1 \\
5 \cdot 1 \\
5 \cdot 1 \\
5 \cdot 15 \\
5 \cdot 15 \\
5 \cdot 3 \\
5 \cdot 35 \\
6 \cdot 3\end{array}$ & $\begin{array}{l}3 \cdot 75 \\
3 \cdot 8 \\
4 \cdot 1 \\
4 \cdot 1 \\
4 \cdot 1 \\
4 \cdot 1 \\
4 \cdot 1 \\
4 \cdot 3 \\
4 \cdot 35 \\
5 \cdot 3\end{array}$ & $\begin{array}{l}2 \cdot 1 \\
1 \cdot 75 \\
2 \cdot 3 \\
2 \cdot 3 \\
2 \cdot 1 \\
2 \cdot 2 \\
2 \cdot 15 \\
2 \cdot 1 \\
2 \cdot 0 \\
1 \cdot 3\end{array}$ & $\begin{array}{l}5 \cdot 0 \\
5.0 \\
5 \cdot 1 \\
5 \cdot 2 \\
5.3 \\
5 \cdot 8 \\
5.8 \\
5.9 \\
5.9 \\
6.3\end{array}$ & $\begin{array}{l}4 \cdot 1 \\
4 \cdot 1 \\
4 \cdot 1 \\
4 \cdot 2 \\
4 \cdot 3 \\
4 \cdot 8 \\
4 \cdot 8 \\
4 \cdot 9 \\
4 \cdot 9 \\
5 \cdot 3\end{array}$ & $\begin{array}{l}5 \cdot 0 \\
6 \cdot 2 \\
5 \cdot 6 \\
4 \cdot 5 \\
4 \cdot 6 \\
4 \cdot 5 \\
5 \cdot 5 \\
8 \cdot 3 \\
4 \cdot 3 \\
3 \cdot 5\end{array}$ \\
\hline \multicolumn{2}{|c|}{ Mean.... } & $5 \cdot 2$ & $4 \cdot 2$ & $2 \cdot 0$ & $5 \cdot 5$ & $4 \cdot 5$ & $5 \cdot 2$ \\
\hline
\end{tabular}

\section{GROWTH IN FAECAL EMULSIONS}

Ten per cent. emulsions of faeces from breast-fed and bottlefed infants were prepared in saline and sterilized by autoclaving. The final $\mathrm{pH}$ in each case was 4.5 and 7.0 respectively. Equal volumes of each suspension were inoculated separately with equal numbers of viable cells of a Gram-negative aerobic bacillus. - Altogether 21 strains were examined, including enteropathogenic E. coli, Vibrio cholerae, Klebsiella and Proteus species, and Ps. aeruginosa.

After 24 hours' anaerobic incubation surface viable counts showed that there had been active multiplication of all strains in the faecal suspensions from bottle-fed infants comparable to that in the nutrient broth control medium, $\mathrm{pH} \mathrm{7.0.} \mathrm{In} \mathrm{the}$ faecal suspensions from breast-fed infants, on the other hand, many strains failed to grow; indeed, some showed a pronounced reduction in viable count. The few strains that grew did so poorly. These results were comparable to those in nutrient broth control medium, $\mathrm{pH} 4.5$.

In comparable experiments performed on a selected group of strains of Gram-negative aerobic bacilli, in which the $\mathrm{pH}$ values of the faecal emulsions were reversed before inoculation, the growth patterns outlined above were also reversed.

\section{GROWTH IN LACTOSE BROTH}

Growth curves and $\mathrm{pH}$ determinations were performed on duplicate cultures of $E$. coli and anaerobic lactobacilli growing in dextrin-free reinforced clostridium medium containing $6 \%$ of lactose. Lactose-free control cultures were included. In all cases the starting $\mathrm{pH}$ was $\mathbf{7 \cdot 4}$ and a standard inoculum, determined by surface viable counts, was used. Two-hourly readings were taken over a period of 34 hours. Cultures of lactobacilli in lactose broth showed a steadily increasing turbidity and a falling $\mathrm{pH}$. At the end of the experiment the organism was still in its logarithmic phase and the $\mathrm{pH}$ had fallen to 3.9. In the lactose-free medium, on the other hand, only slight growth of anaerobic lactobacilli had developed in 34 hours and there was no significant change of $\mathrm{pH}$. Cultures of $E$. coli in lactose broth completed the logarithmic phase by the 24th hour, when the $\mathrm{pH}$ was $5 \cdot 2$. There was good growth of this organism in the lactose-free medium, and the logarithmic phase was complete at 26 hours, when the $\mathrm{pH}$ was $6 \cdot 7$.

\section{MILK FEEDS}

Two basic types of milk are offered to normal newborn infants -breast milk and cow's milk. Though there is a variety of dried cow's milk preparation in general use it is convenient to regard them all as essentially similar. Some of the outstanding differences between breast and cow's milk are summarized in Table III.

TABLE III-Some Major Constituents of Human and Cow's Milk ( $/ 100 \mathrm{ml}$ of Whole Milk)*

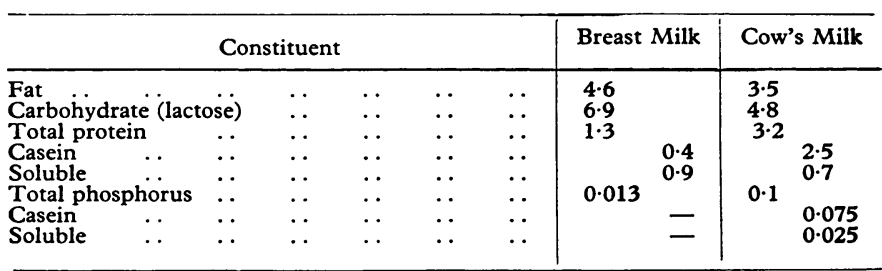

*Information compiled from Oser (1965).

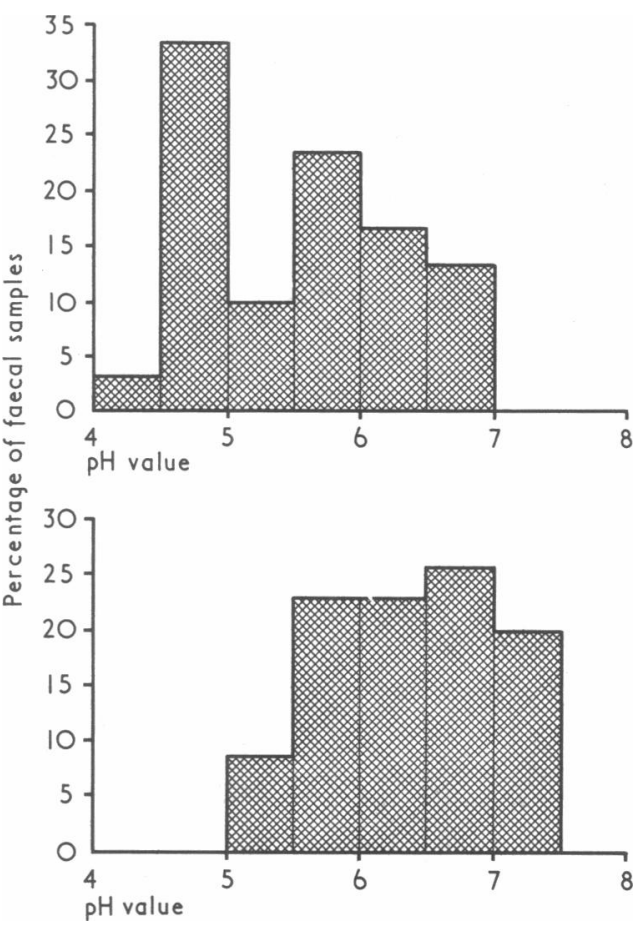

FIG. 4-pH Values of faecal samples from breast-fed and bottle-fed infants distributed as a percentage of each total. (Above: 30 samples from breast-fed infants. Below: 70 samples from bottle-fed infants.)

\section{BUFFERING CAPACITY OF BREAST AND COW'S MILK}

In view of the pronounced difference in the buffering capacity of faeces from infants fed on these two types of milk the buffering capacities of different milks were determined by titration with $\mathrm{N} / 10 \mathrm{HCl}$. The volumes of acid required to reduce the $\mathrm{pH}$ from 7.0 to 5.0 for breast milk, dried cow's milk, and fresh cow's milk were in the ratio $1: 2: 3$. These results are remarkably similar to those for the buffering effects of faeces from infants fed on the two types of milk. 


\section{GROWTH IN BREAST AND COW'S MILK}

In order to study the effect on bacterial growth of the buffering capacity and lactose content of breast and cow's milk a mixed culture of anaerobic lactobacilli and $E$. coli was inoculated into $80-\mathrm{ml}$ volumes of pasteurized breast milk, pasteurized cow's milk, and a dried cow's milk preparation. After 20 and 44 hours' incubation samples from each culture were examined for $\mathrm{pH}$ values and for total viable counts of each organism (Table IV).

As is clear from Table IV both the $E$. coli and lactobacilli grew well in cow's milk preparations in which the lowest $\mathrm{pH}$ reached was $4 \cdot 6$. Both organisms also grew well at first in breast milk; after 20 hours' incubation, however, there was a relative and absolute decrease in the number of viable $E$. coli present, which coincided at 44 hours with a $\mathrm{pH}$ value of 4.0 .

A crude "continuous culture" technique was then used which sought to represent the flow of milk through the infant's intestinal tract. Twenty-millilitre volumes of pasteurized breast and cow's milk were inoculated with a known number of viable cells of $E$. coli and anaerobic lactobacillus. These were incubated at $37^{\circ} \mathrm{C}$ anaerobically for $12-16$ hours. Glass beads were included to break up the curds which developed in the cow's milk cultures. A total of $15 \mathrm{ml}$ of each original culture was withdrawn and replaced by $15 \mathrm{ml}$ of warmed uninoculated pasteurized milk of the same type. The cultures were reincubated for a further 12-16 hours, and this procedure was repeated three times.

Bacterial counts and $\mathrm{pH}$ values were determined on each of the samples taken from the growing cultures. In the cow's milk mixtures the $\mathrm{pH}$ rarely fell below 5.0 ; the $E$. coli count rose rapidly and remained high throughout the experiment, whereas the lactobacillus count rose more slowly. In contrast the breast milk cultures showed a lower $\mathrm{pH}(4 \cdot 0-4 \cdot 5)$ and the $E$. coli count tended to fall in the presence of a high lactobacillus count (Table V).

These results are most easily explained in terms of the different buffering capacities and lactose contents of the two types of milk.

\section{REDUCTION OF BUFFERING CAPACITY OF COW'S MILK}

Because the total protein content of cow's milk is about three times that of breast milk it seemed that the simplest way of reducing this buffering capacity was to reduce the protein content. The buffering capacity of commercial cow's milk whey was compared with that of breast milk. Titrations were performed on samples of whey diluted to contain the same total protein as breast milk. The volume of acid required to reduce the $\mathrm{pH}$ of whey from 6.8 to 5.0 was twice that for breast milk. Since the various protein components of breast and cow's milk are dissimilar, and may also have different buffering capacities, the only other way we were able to account for this difference was to regard the phosphate content as a significant buffer component.

If the figures recorded in Table III for the composition of breast and cow's milk are accepted it is clear that cow's milk whey contains about twice as much phosphate as breast milk. Accordingly, phosphates were removed from whey by mild trypsin digestion, followed by gentle heating and centrifugation. The buffering capacity of the resulting material was virtually the same as that of breast milk.

An alternative approach to this problem was made by preparing an artificial milk containing the phosphate equivalent of breast milk. This was achieved by using that amount of whole cow's milk whey which contained $13 \mathrm{mg}$ of phosphate in $100 \mathrm{ml}$ of final preparation. Bovine albumin, casein, and lactose were added to give a final product which was chemically comparable to breast milk in total and relative amounts of these substances. The buffering capacity of this mixture was virtually identical with that of breast milk.

\section{GROWTH IN BREAST MILK AND COW'S MILK PREPARATIONS}

The highly artificial "milk" preparation described above, together with cow's milk whey and dephosphated cow's milk whey, were compared with breast milk and a commercial dried cow's milk by the continuous culture technique outlined above. The results of this comparison are summarized in Table VI. Though the results are not as clear-cut as those in which cultures were incubated undisturbed for 44 hours (Table IV) the unfavourable effect of low buffered milks (breast milk, artificial milk, and dephosphated cow's milk whey) on the growth of $E$. coli relative to that of lactobacillus is nevertheless quite evident.

\section{Discussion}

From these findings it is clear that the faeces from breast-fed and bottle-fed infants differ in a number of significant ways. They confirm the well established fact that the predominant organism in the faeces of breast-fed babies is an anaerobic lactobacillus, which is present in an acid environment. In

TABLE Iv-Viable Counts per $m l$ and $p H$ of Mixed Cultures in Breast Milk, Cow's Milk, and Dried Cow's Milk

\begin{tabular}{|c|c|c|c|c|c|c|c|c|c|c|c|}
\hline \multirow{2}{*}{\multicolumn{3}{|c|}{ Result }} & \multicolumn{9}{|c|}{ Mixed Culture in } \\
\hline & & & \multicolumn{3}{|c|}{ Breast Milk } & \multicolumn{3}{|c|}{ Cow's Milk } & \multicolumn{3}{|c|}{ Dried Cow's Milk } \\
\hline \multicolumn{3}{|c|}{ Time in hours: } & 0 & 20 & 44 & 0 & 20 & 44 & 0 & 20 & 44 \\
\hline $\begin{array}{l}\text { Anaerobic lactobacillus (viable } \\
E_{\text {. coli (viable count } / \mathrm{ml} \text { ) }}\end{array}$ & $\begin{array}{l}\text { unt } / \mathrm{ml}) \\
\ldots \\
\therefore\end{array}$ & $\begin{array}{l}\cdots \\
\cdots\end{array}$ & $\begin{array}{l}2.8 \times 10^{4} \\
4.4 \times 10^{7} \\
6.0\end{array}$ & $\begin{array}{c}3.5 \times 10^{8} \\
6.0 \times 10^{8} \\
4.7\end{array}$ & $\begin{array}{c}3.0 \times 10^{8} \\
3.5 \times 10^{4} \\
4.0\end{array}$ & $\begin{array}{l}2.8 \times 10^{4} \\
4.4 \times 10^{7} \\
6.0\end{array}$ & $\begin{array}{c}9.5 \times 10^{7} \\
8.0 \times 10^{8} \\
5.3\end{array}$ & $\begin{array}{c}3.0 \times 10^{8} \\
8.0 \times 10^{8} \\
4.8\end{array}$ & $\begin{array}{c}2.8 \times 10^{4} \\
4.4 \times 10^{7} \\
6.0\end{array}$ & $\begin{array}{c}2.0 \times 10^{8} \\
3.0 \times 10^{8} \\
5.0\end{array}$ & $\begin{array}{c}4.5 \times 10^{7} \\
2.0 \times 10^{8} \\
4.6\end{array}$ \\
\hline
\end{tabular}

TABLE v-Viable Counts and pH of "Continuous" Cultures in Breast Milk and Cow's Milk

\begin{tabular}{|c|c|c|c|c|c|c|c|c|c|c|c|}
\hline \multirow{2}{*}{\multicolumn{2}{|c|}{ Result }} & \multicolumn{10}{|c|}{ "Continuous" Cultures in } \\
\hline & & \multicolumn{5}{|c|}{ Breast Milk } & \multicolumn{5}{|c|}{ Cow's Milk } \\
\hline \multicolumn{2}{|c|}{ Time in hours: } & 0 & 12 & 24 & 36 & 48 & 0 & 12 & 24 & 36 & 48 \\
\hline $\begin{array}{l}\text { Anaerobic lactobacillus } \\
\text { (viable count/ml) } \\
E . \text { coli (viable count/mi) } \\
\text { pH of culture .. }\end{array}$ & $\begin{array}{ll}\because & \\
\cdots & \cdots \\
. & \end{array}$ & $\begin{array}{c}4.5 \times 10^{5} \\
7.5 \times 10^{5} \\
6.8\end{array}$ & $\begin{array}{c}10^{7} \\
5 \times 10^{7} \\
4.6\end{array}$ & $\begin{array}{c}10^{8} \\
3 \times 10^{5} \\
4.0\end{array}$ & $\begin{array}{c}1.5 \times 10^{8} \\
2 \times 10^{5} \\
4.3\end{array}$ & $\begin{array}{c}5 \times 10^{7} \\
6.5 \times 10^{5} \\
4.5\end{array}$ & $\begin{array}{c}4.5 \times 10^{5} \\
7.5 \times 10^{5} \\
6.8\end{array}$ & $\begin{array}{c}5 \times 10^{7} \\
10^{8} \\
5.8\end{array}$ & $\begin{array}{c}1.5 \times 10^{7} \\
5 \times 10^{7} \\
4.9\end{array}$ & $\begin{array}{c}1.5 \times 10^{8} \\
5 \times 10^{7} \\
5.2\end{array}$ & $\begin{array}{c}5 \times 10^{5} \\
2 \times 10^{7} \\
5.0\end{array}$ \\
\hline
\end{tabular}


TABLE vi-Total Viable Counts per ml and pH Values of "Continuous" Cultures in Breast Milk, Artificial Milk, Dephosphated Cow's Milk Whey, Cow's Milk Whey, and Dried Cow's Milk

\begin{tabular}{|c|c|c|c|c|c|c|c|c|c|c|c|c|c|c|c|c|c|c|c|c|c|c|c|c|c|}
\hline \multirow{3}{*}{$\begin{array}{c}\text { Results } \\
\text { Time in hours: }\end{array}$} & \multicolumn{25}{|c|}{ "Continuous" Cultures in } \\
\hline & \multicolumn{5}{|c|}{ Breast Milk } & \multicolumn{5}{|c|}{ Artificial Milk } & \multicolumn{5}{|c|}{$\begin{array}{l}\text { Dephosphated } \\
\text { Cow's Milk Whey }\end{array}$} & \multicolumn{5}{|c|}{ Cow's Milk Whey } & \multicolumn{5}{|c|}{ Dried Cow's Milk } \\
\hline & 0 & 16 & 28 & 40 & 52 & 0 & 16 & 28 & 40 & 52 & 0 & 16 & 28 & 40 & 52 & 0 & 16 & 28 & 40 & 52 & 0 & 16 & 28 & 40 & 52 \\
\hline $\begin{array}{l}\text { Anaerobic } \\
\text { lactobacillus } \\
\text { (viable count } / \\
\text { ml) }\end{array}$ & $\begin{array}{c}2 \\
\times \\
10^{8} \\
\end{array}$ & $\begin{array}{c}1.5 \\
\times \\
10^{8}\end{array}$ & $10^{7}$ & $10^{8}$ & $10^{6}$ & $\begin{array}{c}7 \cdot 5 \\
\times \\
10^{5} \\
\end{array}$ & $\begin{array}{c}5 \\
\times \\
10^{7} \\
\end{array}$ & $\begin{array}{c}5 \\
\times \\
10^{7} \\
\end{array}$ & $\begin{array}{c}3 \\
\times \\
10^{8}\end{array}$ & $10^{7}$ & $\begin{array}{c}7.5 \\
\times \\
10^{5} \\
\end{array}$ & $\begin{array}{c}7 \\
\times \\
10^{8} \\
\end{array}$ & $\begin{array}{c}5 \\
\times \\
10^{7}\end{array}$ & $\begin{array}{c}3 \\
\times \\
10^{8} \\
\end{array}$ & $\begin{array}{c}8 \cdot 5 \\
\times \\
10^{7} \\
\end{array}$ & $\begin{array}{c}2 \\
\times \\
10^{6}\end{array}$ & $\begin{array}{c}2 \cdot 5 \\
\times \\
10^{8} \\
\end{array}$ & $\begin{array}{c}6 \cdot 8 \\
\times \\
10^{8} \\
\end{array}$ & $10^{8}$ & $\begin{array}{c}1 \cdot 2 \\
\times \\
10^{9} \\
\end{array}$ & $\begin{array}{c}2 \\
\times \\
10^{6} \\
\end{array}$ & $10^{8}$ & $\begin{array}{c}3.5 \\
\times \\
10^{7}\end{array}$ & $\begin{array}{c}3 \\
\times \\
10^{8}\end{array}$ & $\begin{array}{c}5 \\
\times \\
10^{7}\end{array}$ \\
\hline $\begin{array}{l}E \text {. coli } \\
\text { (viable count/ } \\
\text { ml) }\end{array}$ & $\begin{array}{c}2 \\
\times \\
10^{8}\end{array}$ & $\begin{array}{c}1.5 \\
\times \\
10^{8}\end{array}$ & $\begin{array}{c}5 \cdot 5 \\
\times \\
10^{7}\end{array}$ & $\begin{array}{c}7 \\
\times \\
10^{7}\end{array}$ & $\begin{array}{c}5 \\
\stackrel{x}{x} \\
10^{7}\end{array}$ & $\begin{array}{c}7 \cdot 2 \\
\times \\
10^{5}\end{array}$ & $\begin{array}{c}5 \cdot 5 \\
\times \\
10^{7}\end{array}$ & $\begin{array}{c}1 \cdot 5 \\
\times \\
10^{7}\end{array}$ & $\begin{array}{c}2 \\
\times \\
10^{2}\end{array}$ & $\begin{array}{c}5 \\
\times \\
10^{4}\end{array}$ & $\begin{array}{c}7 \cdot 2 \\
\times \\
10^{5}\end{array}$ & $\begin{array}{c}5 \\
\times \\
10^{4}\end{array}$ & $\begin{array}{r}5 \\
\times \\
10\end{array}$ & $\begin{array}{c}1 \cdot 5 \\
\times \\
10^{4}\end{array}$ & $\begin{array}{c}5 \\
\times \\
10^{3}\end{array}$ & $\begin{array}{c}2 \\
\times \\
10^{6}\end{array}$ & $\begin{array}{c}2 \\
\stackrel{x}{x} \\
10^{8}\end{array}$ & $\begin{array}{c}2 \\
\stackrel{\times}{1} \\
10^{7}\end{array}$ & $\begin{array}{c}5 \\
\times \\
10^{6}\end{array}$ & $\begin{array}{c}2 \\
\times \\
10^{8}\end{array}$ & $\begin{array}{c}2 \\
\times \\
10^{6}\end{array}$ & $\begin{array}{c}5 \cdot 5 \\
\times \\
10^{8}\end{array}$ & $\begin{array}{c}1 \cdot 2 \\
\times \\
10^{9}\end{array}$ & $\begin{array}{c}4 \\
\times \\
10^{8}\end{array}$ & $\begin{array}{c}2 \cdot 5 \\
\times \\
10^{8}\end{array}$ \\
\hline $\mathrm{pH}$ of culture & $6 \cdot 6$ & $4 \cdot 8$ & $4 \cdot 0$ & $4 \cdot 1$ & $4 \cdot 1$ & 6.6 & $4 \cdot 2$ & $4 \cdot 3$ & $4 \cdot 3$ & $4 \cdot 0$ & $6 \cdot 6$ & $4 \cdot 0$ & $4 \cdot 7$ & $4 \cdot 5$ & $4 \cdot 1$ & $7 \cdot 0$ & $4 \cdot 2$ & $3 \cdot 8$ & $4 \cdot 4$ & $4 \cdot 7$ & 6.6 & $5 \cdot 1$ & 4.9 & $4 \cdot 8$ & $4 \cdot 8$ \\
\hline
\end{tabular}

addition, faeces from breast-fed infants have a much higher water content and a lower buffering capacity than those from bottle-fed infants and contain reducing and fermentable substances (probably lactose) which are absent from the faeces of bottle-fed babies. Though the reasons for these clear differences must be a matter for some conjecture the following theoretical considerations seem not unreasonable and receive some support from the results of the in-vitro investigations outlined above.

Bottle-fed infants receive a high-protein, high-phosphorus, low-lactose diet. Most of the protein is caseinogen, which might be expected to clot in the intestinal tract. The passage time through the small intestine of this relatively bulky material would be prolonged, thus providing ample opportunity for absorption of lactose and much of the water content. Thus the material that enters the large intestine might be expected to contain little if any lactose and large amounts of unchanged or partially digested caseinogen. It seems unlikely that all the protein given to a bottle-fed infant would be digested.

In breast-fed infants, on the other hand, the situation would be reversed. The relatively fluid feed, rich in lactose but low in phosphorus and caseinogen, does not readily curd and would traverse the small intestine rapidly, allowing time for only partial absorption of lactose and water. As a result there would be much lactose and water carry-over into the large intestine with little if any caseinogen or phosphate.

If it is assumed that both breast-fed and bottle-fed infants are exposed to the same bacterial contaminants of the intestinal tract it is not difficult to imagine what might happen in the large intestine. Various bacterial species, but especially the $E$. coli/coliform complex and anaerobic lactobacilli, would start to grow, utilizing the nutrients that are injected through the ileocaecal valve. In the early stages of growth the E. coli! coliform complex of organisms would doubtless predominate, since their growth is not greatly influenced by $\mathrm{Eh}$ and because the mean generation time of these organisms is shorter than that of the lactobacillary species. With the development of vigorous "coliform" growth the oxidation-reduction potential of the environment would fall, thus initiating the growth of any lactobacilli present.

Concurrently with bacterial growth, fermentation of any lactose present would lead to the production of acid and there would be a tendency for the $\mathrm{pH}$ to fall. In infants fed on cow's milk acid production would be minimal because of the near absence of lactose, and any acid produced would be neutralized by the high buffering effect of the large bowel content. In breast-fed infants, however, active lactose fermentation would produce and liberate acid into a poorly buffered environment and the $\mathrm{pH}$ would tend to fall. This falling $\mathrm{pH}$ would directly favour the growth of anaerobic lactobacilli and would ultimately lead to conditions that are unfavourable for the growth of Gram-negative enteric organisms. The falling $\mathrm{pH}$ would also have an indirectly favourable effect on the anaerobic lactobacilli, for it would enable them to grow at a relatively high oxidation-reduced potential.

With these dynamic processes initiated in the large bowel more material (at the next feed) would enter the colon from the small intestine; in a bottle-fed baby the buffering properties and low lactose content of this material would reverse any tendency of the $\mathrm{pH}$ of the large bowel content to fall. In a breast-fed infant, however, the poor buffering effect of the material would do little to adjust the already falling $\mathrm{pH}$ and would provide additional lactose for hydrolysis to acid. In this way a continuous culture would be set up in the infant colon, the culture being supplemented at about four-hourly intervals with nutrients, lactose, and buffer in amounts dependent on the nature of the feed.

Various explanations have been put forward to account for the resistance of breast-fed babies to gastroenteritis. These include the passive transfer of antibodies to enteropathogenic $E$. coli in colostrum (Sussman, 1961), contamination of artificial feeds during preparation (Neter, 1959), and the nature of the intestinal environment (Ross and Dawes, 1954). In their detailed and excellent study of the problem Ross and Dawes concluded that the preponderance of lactobacilli in the faeces of breast-fed infants and the relatively low $\mathrm{pH}$ of the large bowel content were the main factors responsible for natural resistance to enteric infections. They found that oral feeds of lactose had only a partial and temporary effect in reducing the $\mathrm{pH}$ of the faeces of artificially fed babies, and they suggested that human milk must contain another factor necessary for the maintenance of an acid $\mathrm{pH}$ and a lactobacillary flora.

The results of the present study are in general agreement with the observations and conclusions of Ross and Dawes. Though there may well be "another factor" in human milk (György et al., 1954) that either encourages the growth of anaerobic lactobacilli or suppresses that of $E$. coli, our findings point to the importance of the ingredients and properties of cow's milk, which seem to provide an intestinal content that is unfavourable both to the growth of lactobacilli and to the production of an acid environment.

In a recent discussion of other problems of infant feeding it has been asserted that "the infant should be fed when hungry and be satisfied by each feed" and that "two new milks are required: one for the newborn, suitably low in osmolality and phosphorus content and not productive of hypocalcaemia . . ." (Lancet, 1971). These observations are pertinent also to the present study. The presence of excess of phosphate in cow's milk seems to be an important factor responsible for its unacceptably high buffering capacity; it will be recalled that the buffering ratios breast milk:cow's milk whey: dephosphated cow's milk whey were $1: 2: 1$. The value of demand feeding might lie in the fact that undue periods of starvation and subsequent overfeeding that must be common in bottle-fed infants would be avoided. There is good evidence 
to suggest that starvation decreases the resistance of experimental animals to Gram-negative enteric infections, and overeating is known to play an essential part in the development of enterotoxaemia in sheep and possibly in man (Freter, 1955; Bullen and Scarisbrick, 1957; Formal et al., 1958; Murrell and Roth, 1963; Murrell et al., 1966).

In-vivo experiments are at present being planned with a view to producing a breast-fed type of faecal flora and large bowel environment in bottle-fed babies.

Sir James Howie suggested this problem to us and we are grateful for his interest and encouragement in the work. We are greatly indebted to Dr. J. D. Hall, Miss W. Parr, and Sister A. Bourne, who arranged for us to receive samples of infant faeces; and Messrs. Unigate and Messrs. Trufood for suppyling dried cow's milk preparations. Our thanks are also due to Mr. M. G. Day, who kindy performed some of the chemical investigations, and to Mrs. K. Williams for invaluable technical assistance.

\section{References}

Alexander, M. B. (1948). British Medical fournal, 2, 973. Bullen, J. J., and Scarisbrick, R. (1957). Fournal of Pathology and Bacteriology,

Formal, S. B., Dammin, G. J., La Brec, E. H., and Schneider, H. (1958). fournal of Bacteriology, 75, 604 .

Freter, R. (1955). Fournal of Infectious Diseases, 97, 57.

György, P., Norris, R. F., and Rose, C. S. (1954). Archives of Biochemistry and Biophysics, 48, 193.

Hinton, N. A., and MacGregor, R. R. (1958). Canadian Medical Association Fournal, 79, 359.

Lancet, 1971, 1, 30.

Miles, A. A., Misra, S. S., and Irwin, J. O. (1938). fournal of Hygiene,

38, 732. G. C., and Roth, L. (1963). Medical fournal of Australia, 1,61 .

Murrell, T. G. C., Egerton, J. R., Rampling, A., Samels, J., and Walker, P. D. (1966). Fournal of Hygiene, 64, 375.

Neter, E. (1959). Fournal of Pediatrics, 55, 223.
Oser, B. L. (1965). Hawk's Physiological Chemistry, 14th edn., p. 369. New York, McGraw-Hill.

Ross, C. A. C., and Dawes, E. A. (1954). Lancet, 1, 994.

Sussman, S. (1961). Pediatrics, 27, 308.

\title{
Potentially Serious Side Effects of High-dose Twice-weekly Rifampicin
}

\author{
GRAHAM POOLE, PETER STRADLING, SHEILA WORLLEDGE
}

British Medical fournal, 1971, 3, 343-347

\section{Summary}

Daily rifampicin in a single dose of $600 \mathrm{mg}$, combined with other drugs, usually streptomycin and isoniazid, was given to 49 patients for three months. It was planned to continue for another 15 months with twice-weekly rifampicin $1,200 \mathrm{mg}$ plus isoniazid $900 \mathrm{mg}$, but the high incidence of side effects led to cessation of the intermittent regimen when only two patients had completed 18 months.

Though there was no serious problem with daily treatment 11 patients $(22 \%)$ were unable to continue rifampicin on the intermittent regimen. In $8(16 \%)$ a pyrexial syndrome occurred. In one of these patients there was also temporary renal failure, and in another precipitous thrombocytopenia led to epistaxis and bleeding into the tongue and lips. Symptomless thrombocytopenia developed in two other patients, making three cases $(6 \%)$ of thrombocytopenia in all.

In $16(33 \%)$ of the 49 patients antibodies to rifampicin were detected in the blood. Side effects occurred in 9 $(56 \%)$ of these, including the three developing thrombocytopenia, but in only $2(6 \%)$ of the 33 patients with no antibodies detected. This association of toxic reactions with antibodies is highly significant $(\mathbf{P}<0.001)$.

\section{Introduction}

Laboratory reports on rifampicin suggest that it is one of the most effective antituberculosis drugs yet discovered (Verbist and Gyselen, 1968), and clinical results are highly encouraging Royal Postgraduate Medical School, Hammersmith Hospital, London
W12 OHS

GRAHAM POOLE, M.B., M.R.C.P., Lecturer in Respiratory Diseases

PETER STRADLING, M.D., F.R.C.P., Senior Lecturer in Respiratory Diseases

SHFII.A WORLLEDGE, M.B., F.R.C.PATH., Senior Lecturer in Haematology
(Gyselen et al., 1969). The only appreciable side effect reported when the drug is used on a daily basis is jaundice, which is particularly likely to occur in alcoholics (Lesobre et al., 1969; Lees et al., 1970). Laboratory work further suggests that rifampicin should be highly effective in intermittent regimens (Batten, 1969; Grumbach et al., 1969; Dickinson and Mitchison, 1970).

We started a clinical trial of intermittent rifampicin therapy in the summer of 1969 . This preliminary report on side effects of rifampicin is made to warn others that our experience suggests that rifampicin, when used twice-weekly at a dosage of $1,200 \mathrm{mg}$, can result in an unacceptably high incidence of toxicity. One side effect encountered (thrombocytopenia) is potentially extremely serious and was first recognized by Farga (1970). A case of immune thrombocytopenia with rifampicin antibodies detected by reaction with platelets and red cells has already been reported from this school (Blajchman et al., 1970), and two more have subsequently occurred, together with a case of transient renal failure.

\section{Materials and Methods}

REGIMEN

The trial regimen planned, and used in most cases, was intramuscular streptomycin $0.75 \mathrm{~g}$, oral isoniazid $300 \mathrm{mg}$, and oral rifampicin $600 \mathrm{mg}$ on six days a week for three months, followed by twice-weekly rifampicin $1,200 \mathrm{mg}$, with isoniazid $900 \mathrm{mg}$, plus pyridoxine $10 \mathrm{mg}$ for a further 15 months. Appropriate dosage adjustments were made for the two children in the series. Administration of all doses to all patients was fully supervised.

\section{PATIENTS}

All newly-diagnosed tuberculous patients with tuberculosis attending the chest clinic at Hammersmith Hospital from 1 July 1969 were considered for inclusion in the trial. Also included in this toxicity study were three patients who received, 